\title{
Causes of death among people living with HIV/AIDS in Brazil
}

Authors

Erika Luiza Lage Fazito Rezende $^{1}$

Ana Maria Nogales

Vasconcelos ${ }^{2}$

Mauricio Gomes Pereira ${ }^{3}$

${ }^{1}$ Master in Epidemiology, Technical advisor at the Department of STI, AIDS and Viral Hepatitis/ Health Surveillance Secretariat,

Ministry of Health.

${ }^{2}$ Doctor in Demography, Professor at the

Department of Statistics, Universidade de Brasília.

${ }^{3}$ Doctor in Epidemiology, Professor at the Collective Health Department,

Universidade de Brasília.

\begin{abstract}
Background: The monitoring of the underlying causes of death in people living with HIV/AIDS is important so that actions to reduce morbidity and mortality can be taken. Objective: To describe the temporal trends of underlying causes of death among people living with HIV/AIDS between 2000 and 2007 in Brazil and to identify factors associated with it. Methods: The Mortality Information System data for deaths occurred in Brazil between 2000 and 2007 that contained reference to HIV/ AIDS in any of the death certificate fields was analyzed. Temporal trends of the underlying cause of death were studied. Differences in the underlying cause of death according to gender, age, region of residence, level of education, certifying officer, race and year of death were verified. Results: Between 2000 and 2007 the percentage of deaths not related to HIV/AIDS among people living with HIV/ AIDS increased from 2.5\% to 7.0\%. People with higher level of formal education, living in the SouthEast region of Brazil and aged under 13 or over 60 years old were more likely to have their underlying cause of death reported as not related to HIV/AIDS. Conclusion: The results suggest the importance of implementing actions aimed at improving the quality of life of PLWHA, and which could include behavioral changes, such as smoking and alcoholism cessation, early screening to detect neoplasms and the monitoring of chronic conditions, such as diabetes. That is to say, the need exists to integrate the actions of HIV/AIDS programs with other public health programs.
\end{abstract}

Keywords: AIDS; causes of death; HIV.

[Braz J Infect Dis 2010;14(6):558-563]@Elsevier Editora Ltda.

\section{INTRODUCTION}

Submitted on: 03/01/2010 Approved on: 06/21/2010

Correspondence to: Erika Luiza Lage Fazito Rezende

Departamento de DST, Aids e Hepatites Virais Unidade de Informação e Vigilância

SAF Sul Trecho 02,

Bloco F, Torre I, Edifício

Premium, Térreo, Sala 12 70070-600 - Brasília - DF Brazil

Phone: +55 61 3306-7085 E-mail: erika.fazito@aids. gov.bror erikafazito@ gmail.com

Financial Support: Centers for Disease Control and Prevention, Global Aids Program Brazil (CDC/GAP-Brazil)

We declare no conflict of interest.
As of June 2009, 544,846 AIDS cases had been identified in Brazil, with an average annual incidence of 35,000 cases over the last five years. The AIDS incidence rate can be seen to have stabilized at 19.0/100,000 inhabitants. ${ }^{1}$

The official statistics on AIDS mortality in Brazil are compiled based on the number of deaths registered on the Mortality Information System (Sistema de Informações sobre Mortalidade - SIM) having AIDS as their underlying cause of death (International Code of Diseases- ICD 10: B20 to B24). The underlying cause of death is selected based on what is reported by the certifying doctor, in accordance to the rules established by the World Health Organization (WHO). ${ }^{2}$

In order to put these rules into operation, the Primary Causes Selection System
(Seletor de Causas Básicas - SCB-10) was adopted by the Ministry of Health to read the codes of the diagnoses contained on the International Form of Medical Certificate of Cause of Death, which is included in Part IV of the Brazilian Death Certificate, and to interpret and process the diagnoses in accordance with the provisions of the ICD-10 mortality rules, automatically selecting the underlying cause of death and recording the data on the causes associated with death. ${ }^{3}$

Between 1980 and 2008, 217,091 AIDS deaths (ICD 10: B20 to B24) were reported in Brazil. In the 1980s, there was an exponential increase in the number of deaths (one death in 1980 increasing to 3,274 in 1989). In the 1990s, the maximum number of deaths was reached $(15,156$ deaths in 1995 , half of which occurred in the State of São Paulo) and has now stabilized at around 11,000 deaths a year. ${ }^{1}$ 
The universal and free access to highly active antiretroviral therapy (HAART) in Brazil since 1996 caused a notable impact on morbidity and mortality. The AIDS mortality coefficient varied from 9.6/100,000 inhabitants in 1996 to 6.0 in 2006, remaining stable at this level in the country as a whole. ${ }^{1}$

Universal access to HAART has also led to increased survival time among adults and children with AIDS. The probability of being alive 60 months after diagnosis was 58.3\% in children diagnosed in 1995 and 1996, ${ }^{4}$ rising to $86.3 \%$ in children diagnosed between 1999 and 2002. ${ }^{5}$ Average survival time in adults increased from 58 months in patients diagnosed in $1996^{6}$ to more than 108 months in those diagnosed between 1998 and 1999. ${ }^{7}$

Within this new context, it has become necessary to understand (I) the underlying causes of death among people living with HIV and AIDS (PLWHA), (II) the changes in these causes over time, and (III) the factors associated with the underlying causes of death in order to implement policies to reduce morbidity and mortality among PLWHA.

\section{METHODS}

This is a cross-sectional study using secondary information from the Brazilian Mortality Information System (SIM).

Since 1999 the Ministry of Health has made available, through SIM, data on causes of death (underlying and associated) registered on death certificates, thus enabling the selection of deaths having codes related to HIV/AIDS in any of the death certificate fields.

The year 1999 was not included in the analysis due to the large amount of unknown or missing information, as well as different variable categorization in relation to the following years. Therefore, the analysis focuses on data registered in SIM between 2000 and 2007, in which HIV/ AIDS were mentioned as the underlying or associated cause of death (Table 1). The term "PLWHA deaths" are used in this paper to refer to such deaths.

The underlying causes were categorized as HIV/AIDS (ICD 10 codes in Table 1) and non-HIV/AIDS (other ICD 10 codes). The following variables were analyzed: gender (female and male), age group ( $<12 ; 13$ to $24 ; 25$ to $39 ; 40$ to 50 ; and 60 years or more), the certifying doctor, that is to say, the doctor who signs the DC (doctor responsible for the patient; other doctors; and Forensic Medicine Institutes or Death Verification Services), race (white and non-white), level of formal education (illiterate; incomplete basic education; complete basic education and incomplete or complete secondary education; incomplete or complete higher education; and unanswered), region of residence (North, North-East, South-East, South and Midwest regions) and year of death (2000 to 2007).
The temporal trends of the underlying cause of death among PLWHA were analyzed and the chi-square test and odds ratios were calculated to verify whether there were differences in the selection of the underlying cause of death according to gender, age group, region of residence, level of education, race and year of death. A logistic regression model was adjusted for the 2006 and 2007 data in order to verify the association and measure the effects of these variables on the selection of the underlying cause of death.

The database used in this study is not nominal and does not contain any form of identification of the subjects studied. Brazilian mortality data is available free of charge on the following website http://tabnet.datasus. gov.br/tabdata/sim/dados/cid10_indice.htm.

The statistical analysis of the data was performed using SPSS software. ${ }^{8}$

Table 1. HIV/AIDS infection codes as per the International Classification of Diseases - 10th Revision (ICD 10)*

\begin{tabular}{|ll|}
\hline Code & Definition \\
\hline B20 & $\begin{array}{l}\text { Human immunodeficiency virus [HIV] disease, } \\
\text { resulting in infectious and parasitic diseases }\end{array}$ \\
\hline B21 & $\begin{array}{l}\text { Human immunodeficiency virus [HIV] disease, } \\
\text { resulting in malignant neoplasms }\end{array}$ \\
\hline B22 & $\begin{array}{l}\text { Human immunodeficiency virus [HIV] disease } \\
\text { resulting in other specified diseases }\end{array}$ \\
\hline B23 & $\begin{array}{l}\text { Human immunodeficiency virus [HIV] disease } \\
\text { resulting in other conditions }\end{array}$ \\
\hline B24 & $\begin{array}{l}\text { Unspecified human immunodeficiency virus } \\
\text { [HIV] disease }\end{array}$ \\
\hline F02.4 & $\begin{array}{l}\text { Dementia in human immunodeficiency virus } \\
\text { [HIV] disease }\end{array}$ \\
\hline R75 & $\begin{array}{l}\text { Laboratory evidence of human immunodefi- } \\
\text { ciency virus [HIV] disease }\end{array}$ \\
\hline Z11.4 & $\begin{array}{l}\text { Special screening examination for human } \\
\text { immunodeficiency virus [HIV] }\end{array}$ \\
\hline Z20.6 & $\begin{array}{l}\text { Contact with and exposure to human } \\
\text { immunodeficiency virus [HIV] }\end{array}$ \\
\hline Asymptomatic human immunodeficiency \\
virus [HIV] infection status
\end{tabular}

Sources: ICD-10 International Statistical Classification of Diseases and Related Health Problems Tenth Revision, Version for 2008, Volume I.

* Brasil. Ministério da Saúde. Secretaria de Vigilância em Saúde. Programa Nacional de DST e AIDS. Critérios de definição de casos de AIDS em adultos e crianças./ Ministério da Saúde, Secretaria de Vigilância em Saúde, Programa Nacional de DST e Aids. Brasília: Ministério da Saúde, 2005. 


\section{RESULTS}

In Brazil, between 2000 and 2007, there were 92,111 deaths among PLWHA (whose death certificates mention HIV/ AIDS in one or more fields), representing an annual average of 11,500 PLWHA deaths.

The majority of PLWHA deaths occurred in a hospital (92.8\%), in men (67.8\%), bachelors (61.0\%), aged 30 to 49 years old $(65.0 \%)$, white $(52.1 \%)$ and resided in the SouthEast Region (56.7\%). The underlying cause was HIV/AIDS in $96.1 \%$ of deaths and the doctor caring for the patient signed the death certificate in $38.7 \%$ of the cases.

With effect from the year 2000, an increase in non-HIV/ AIDS deaths can be seen, varying from 270 deaths (2.5\%) in 2000 , to 850 deaths $(7.0 \%)$ in 2007 . It is noteworthy that between 2005 and 2006 this number more than doubled (Table 2). The five principal non-HIV/AIDS underlying causes of deaths in PLWHA are (Table 3):

- Malignant primary neoplasms in specificlocations (22.4\%), $57.0 \%$ of which relate to digestive and respiratory organs.

- Circulatory system diseases (16.5\%).

Table 2. PLWHA death distribution by year of death and underlying cause of death. Brazil, 2000 to 2007

\begin{tabular}{lccccc}
\hline \multirow{2}{*}{$\begin{array}{l}\text { Year of } \\
\text { death }\end{array}$} & \multicolumn{4}{c}{ Underlying cause } & Total \\
& \multicolumn{1}{c}{ HIV/AIDS } & \multicolumn{2}{c}{ Other } \\
$\mathbf{n}$ & $\mathbf{\%}$ & $\mathbf{n}$ & $\%$ \\
\hline 2000 & 10,722 & 97.5 & 270 & 2.5 & 10,992 \\
\hline 2001 & 10,946 & 97.4 & 290 & 2.6 & 11,236 \\
\hline 2002 & 11,053 & 97.1 & 330 & 2.9 & 11,383 \\
\hline 2003 & 11,263 & 97.1 & 341 & 2.9 & 11,604 \\
\hline 2004 & 11,017 & 96.8 & 368 & 3.2 & 11,385 \\
\hline 2005 & 11,097 & 97.0 & 347 & 3.0 & 11,444 \\
\hline 2006 & 11,046 & 93.2 & 800 & 6.8 & 11,846 \\
\hline 2007 & 11,371 & 93.0 & 850 & 7.0 & 12,221 \\
\hline Total & 88,515 & 96.1 & 3596 & 3.9 & 92,111 \\
\hline & & & & & \\
\hline
\end{tabular}

Table 3. Principal non-HIV/AIDS related underlying causes of death in PLWHA. Brazil, 2000 to 2007

\begin{tabular}{lcc}
\hline Underlying causes of death & \multicolumn{3}{c}{ Frequency } \\
& n & \% \\
\hline $\begin{array}{l}\text { Malignant primary neoplasms } \\
\text { in specific locations }\end{array}$ & 804 & 22.4 \\
\hline Circulatory system diseases & 592 & 16.5 \\
\hline Digestive system diseases & 575 & 16.0 \\
\hline Endocrine, nutritional and metabolic diseases & 266 & 7.4 \\
\hline External causes of morbidity and mortality & 240 & 6.7 \\
\hline Respiratory diseases & 220 & 6.1 \\
\hline Viral hepatitis & 159 & 4.4 \\
\hline
\end{tabular}

- Digestive system diseases, of which $42.0 \%$ were alcoholic liver disease.

- Endocrine, nutritional and metabolic diseases, of which $76.0 \%$ were diabetes mellitus.

- External causes of morbidity and mortality.

It is important to note that between 2000 and 2005 acute viral hepatitis accounted for less than $1.0 \%$ of non-HIV/AIDS deaths, whereas in 2006 and 2007 the frequency of these diseases increased to $8.1 \%$ and $8.8 \%$.

There is a difference in the profile of PLWHA deaths between the periods of 2000-2005 and 2006-2007, since (I) the number of non-HIV/AIDS deaths in 2006 is more than double that of 2005, (II) it is only in 2006 and 2007 that viral hepatitis appears among the primary causes of these deaths, and (III) the procedure used to select the underlying cause of death in 2006 and 2007 is different from the procedure applied in the other years. As such, a logistic regression model was adjusted only in relation to deaths occurred in 2006 and 2007 to measure the effect of the independent variables on the selection of the underlying cause of death in PLWHA.

Univariate analysis showed that the region of residence, race, age group, level of education and certifying doctor are associated with the underlying cause of death in PLWHA. Therefore, these variables were included in the initial logistic regression model.

The region of residence, age group, certifying doctor and race maintained significant association with the selection of the underlying cause following the adjustment of the logistic regression model (Table 4).

Table 4. Final multivariate analysis model, $p$ value, $O R$ and confidence interval. Brazil, 2006 and 2007

\begin{tabular}{|c|c|c|c|c|c|}
\hline \multirow[t]{2}{*}{ Variables } & \multirow[t]{2}{*}{ Categories } & \multirow[t]{2}{*}{$p$ value } & \multirow[t]{2}{*}{ OR } & \multicolumn{2}{|c|}{ CI $95 \%$} \\
\hline & & & & $\begin{array}{c}\text { Lower } \\
\text { limit }\end{array}$ & $\begin{array}{l}\text { Upper } \\
\text { limit }\end{array}$ \\
\hline \multirow{5}{*}{$\begin{array}{l}\text { Region of } \\
\text { residence }\end{array}$} & North & & 1.00 & & \\
\hline & North-East & 0.932 & 1.02 & 0.71 & 1.46 \\
\hline & South-East & 0.001 & 1.71 & 1.25 & 2.33 \\
\hline & Midwest & 0.371 & 0.82 & 0.54 & 1.26 \\
\hline & South & 0.059 & 1.38 & 0.99 & 1.93 \\
\hline \multirow{5}{*}{$\begin{array}{l}\text { Age } \\
\text { group }\end{array}$} & $\geq 60$ years & 1.00 & & & \\
\hline & $\leq 12$ & 0.155 & 0.74 & 0.48 & 1.12 \\
\hline & 13 to 24 & $<0.001$ & 0.26 & 0.18 & 0.40 \\
\hline & 25 to 39 & $<0.001$ & 0.33 & 0.27 & 0.41 \\
\hline & 40 to 59 & $<0.001$ & 0.58 & 0.48 & 0.71 \\
\hline \multirow{3}{*}{$\begin{array}{l}\text { Certifying } \\
\text { officer }\end{array}$} & Doctor in charge & 1.00 & & & \\
\hline & Other doctor & 0.152 & 0.91 & 0.81 & 1.03 \\
\hline & FMI/DVS & $<0.001$ & 1.88 & 1.52 & 2.33 \\
\hline \multirow[t]{2}{*}{ Race } & White & & 1.00 & & \\
\hline & Non-white & 0.013 & 0.85 & 0.75 & 0.97 \\
\hline Constant & & $<0.001$ & 0.12 & & \\
\hline
\end{tabular}


Deaths in the South-East region can be seen to differ significantly from those in the other regions, with higher probability of the selection of non-HIV/AIDS underlying causes.

Individuals aged under 13 years old did not present a significant difference in relation to the selection of the underlying cause when compared to those aged 60 and above. In all the other age groups, however, there is a greater probability of non-HIV/AIDS underlying causes of death.

Death certificates issued by Forensic Medicine Institute (FMI) or Death Verification Services (DVS) were 90\% more likely to state non-HIV/AIDS underlying causes than those issued by the doctor in charge of the patient.

Deaths in non-white individuals are more likely to have HIV/AIDS as their underlying cause than those in white individuals.

\section{DISCUSSION}

The data shows that the proportion of non-HIV/AIDS deaths in PLWHA is increasing. Other authors have also identified similar trends. Krentz et al. studied 560 deaths of PLWHA, who lived in Southern Alberta, Canada, between 1984 and 2003 and found an increase in the proportion of deaths not related to HIV/AIDS from $7 \%$ in 1997 to $32 \%$ after $1997 .{ }^{9}$ In a prospective study performed on a cohort of patients attending the Johns Hopkins AIDS Center, Lau et al. found an increased mortality rate in PLWHA owing to causes not related to HIV/AIDS from 10.7 deaths/1,000 people per annum in 1997 to 22.7 in $2003 .{ }^{10}$ In a population-based cohort in New York, USA, Sackoff et al. noted that the percentage of PLWHA deaths not related to HIV/ AIDS increased from $19.8 \%$ in 1999 to $26.3 \%$ in $2004 .{ }^{11}$ A retrospective study of 1,224 deaths of United States Department of Defense beneficiaries found that the proportion of PLWHA deaths attributed to causes not related to HIV/AIDS increased significantly during the period studied: $9 \%$ up to 1996, 28\% from 1997 to 1999 and $32 \%$ from 2000 to $2003 .{ }^{12}$

In Brazil, Pacheco et al. analyzed death certificates data for all deaths occurred between 1999 and 2004. The authors compared death certificates making any mention of HIV/AIDS (HIV group) with the other death certificates (non-HIV group). The results showed an increase of causes not related to HIV/AIDS from $16.3 \%$ in 1999 to $24.1 \%$ in 2004. ${ }^{13}$ The selection of the HIV group was similar to our study, but the definition of causes related to HIV/AIDS was different and that explains the difference in the magnitude of the frequency of non-HIV/AIDS related deaths between the two studies.

Analogically, other studies have found a decrease in the proportion of PLWHA deaths that had HIV/AIDS as the underlying cause. ${ }^{14-18}$
In our study, the principal non-HIV/AIDS underlying causes are neoplasms, circulatory system diseases, diseases of the digestive system (alcoholic liver disease being the most prevalent) and diabetes mellitus. This result is similar to that found by several authors. ${ }^{10,12-19,21}$ Other commonly found causes in the literature were infections, ${ }^{15,16,19,20}$ respiratory diseases ${ }^{12,17}$ and external causes. ${ }^{10,20}$ It is important to highlight that external causes accounted for $8.0 \%$ of nonHIV/AIDS deaths in this study, being the fifth most frequent underlying cause of death.

The presence of diabetes mellitus on the list may be due to the association between HAART use and diabetes mellitus incidence in HIV-infected patients, principally among those taking protease inhibitors. ${ }^{20-23}$ Alcoholic liver disease may be due to the fact that people with exaggerated alcohol consumption are more likely to engage in HIV infection risk behaviors such as, for example, injecting drug users sharing syringes, ${ }^{24}$ risky sexual behavior, such as multiple partners, unprotected sex, sex with high risk partners and sex in exchange for money. ${ }^{25-28}$

Between 2005 and 2006 the number of PLWHA deaths with underlying causes not related to HIV/AIDS increased from $3.0 \%$ to $7.0 \%$. This increment was higher than expected and may represent the effect of the new algorithm for selecting underlying causes of death applied to the 2006 and 2007 data. This algorithm may also have been responsible for the appearance of acute viral hepatitis for the first time on the list of non-HIV/AIDS underlying causes. This underlying cause of death selection mechanism was developed to replace the former one which, when selecting the underlying cause of death, transformed ICD-10 references into ICD-9 ones and, after selection, modified the underlying cause of death code back to ICD-10. Transformation to ICD-9 is no longer necessary. As the years 2006 and 2007 presented a considerably different profile when compared to the other years studied, we suggest that the new underlying cause selection mechanism be applied to the 1999 to 2005 data, when ICD-10 was already in force and the Ministry of Health already made the references to causes of death available.

The multivariate analysis showed that older white people, with higher levels of education and resident in the South-East region tend to have non-HIV/AIDS causes as the underlying cause of death. This data suggests inequality in health care and in access to antiretroviral medication, since the probability of a patient who has never taken medication dying of AIDS is greater than that of a patient being treated with HAART. ${ }^{10}$ Some authors have also reported that older white people with a more recent diagnosis are more likely to die of non-HIV/AIDS related causes. ${ }^{12,21}$ Advanced age is associated with deaths caused by neoplasms and liver diseases in PLWHA, ${ }^{20,29}$ whereas those who died from HIV/AIDS related causes were younger, had lower CD4 counts, higher viral loads and low socioeconomic conditions. ${ }^{16,21}$ 
The results suggest the importance of implementing actions aimed at improving the quality of life of PLWHA, and which could include behavior changes, such as smoking and alcoholism cessation, early screening to detect neoplasms and the monitoring of chronic conditions, such as diabetes. That is to say, the need exists to integrate the actions of HIV/ AIDS programs with other public health programs.

This study has some limitations, firstly, with regard to the coverage and the quality of the Mortality Information System data, which are unequally distributed throughout the country. Secondly, as analysis was only performed on the data contained on the Death Certificates, important information about possible confusing factors could not be taken into consideration, such as HAART use, CD4 counts, behavioral factors such as smoking and alcoholism and the interval of time since HIV infection was diagnosed. Finally, the change in the underlying cause coding system in 2006 limited the temporal analysis of the underlying causes of death in PLWHA and, for this reason, we suggest that the new underlying cause of death coding system be applied retrospectively with effect from 1999.

\section{ACKNOWLEDGEMENTS}

This publication received the support of HHS Centers for Disease Control and Prevention (CDC), National Center for HIV, viral Hepatitis, STD and TB Prevention (NCHHSTP), Global AIDS Program (GAP) Cooperative Agreement.

Its contents are of the sole responsibility of the authors and do not necessarily represent the official CDC position.

\section{REFERENCES}

1. Brasil. Ministério da Saúde. Secretaria de Vigilância em Saúde. Programa Nacional de DST e Aids. Boletim Epidemiológico AIDS DST, ano V, no 1, 2008. http://www.aids.gov.br/data/documents/storedDocuments/\{B8EF5DAF-23AE-4891-AD361903553A3174\}/\{31A56BC6-307D-4C88-922D-6F52338D0BF4\}/Boletim2008_versão1_6.pdf. Access: 03/20/2009.

2. Organização Mundial de Saúde. CID-10: Classificação Estatística Internacional de Doenças e Problemas Relacionados à Saúde - Décima revisão. 2008. Volume 1. Available at: http:// www.datasus.gov.br/cid10/v2008/cid10.htm.

3. Pinheiro CE, Santo AH. Processamento de causas de morte em lote pelo sistema de seleção de causa básica. Rev. Saúde Pública 1998; 32(1):72-3. Available at: http://www.scielosp.org/scielo. php?script $=$ sci_arttext\&pid $=$ S0034-89101998000100010. Accessed on 05/27/2009.

4. Matida LH, Ramos Jr NA, Moncau JEC et al. AIDS by motherto-child transmission: survival analysis of cases followed from 1983 to 2002 in different regions of Brazil. Cad Saúde Pública (FIOCRUZ) 2007; 23(S3):435-44. http://www.scielo.br/pdf/ csp/v23s3/11.pdf. Accessed: 03/20/2009.

5. Matida LH, Ramos Jr AN, Marques HHS et al. Ampliação da sobrevivência de crianças com aids: uma resposta brasileira sustentável. In: Brasil, Ministério da Saúde, Secretaria de Vigilância em Saúde. Programa Nacional de DST e Aids. Boletim Epidemiológico AIDS DST, ano V, no 1,2008. http://www.aids.gov.br/data/
documents/storedDocuments/\{B8EF5DAF-23AE-4891-AD361903553A3174\}/\{31A56BC6-307D-4C88-922D-6F52338D0BF4\}/Boletim2008_versão1_6.pdf. Accessed: 03/20/2009.

6. Marins JR, Jamal LF, Chen SY et al. Dramatic improvement in survival among adult Brazilian AIDS patients. Aids 2003; 17:1675-1682.

7. Guibu IA, Barros MBA, Cordeiro MRD et al. Estudo de Sobrevida de Pacientes de AIDS no Brasil, 1998 a 1999 - Fase I - Regiões Sul e Sudeste. In: Brasil, Ministério da Saúde, Secretaria de Vigilância em Saúde. Programa Nacional de DST e Aids. Boletim Epidemiológico AIDS DST, ano V, no 1, 2008. http://www.aids.gov.br/data/documents/storedDocuments/\{B8EF5DAF-23AE-4891-AD361903553A3174\}/\{31A56BC6-307D-4C88-922D-6F52338D0BF4\}/Boletim2008_versão1_6.pdf. Access: 03/20/2009.

8. SPSS [computer program]. Version 13.0 for windows. Release 13.0 (1 Sep 2004). Copyright (C SPSS Inc., 1989-2004. All rights reserved. Network license user: Ministério da Saúde.

9. Krentz HB, Kliewer G, Gill MJ. Changing mortality rates and causes of death for HIV-infected individuals living in Southern Alberta, Canada from 1984 to 2003. HIV Med. 2005; 6:99-106. [PMID: 15807715].

10. Lau B, Gange SJ, Moore RD. Risk of non-AIDS-related mortality may exceed risk of AIDS-related mortality among individuals enrolling into care with CD4+ counts greater than 200 Cells/mm3. J Acquir Immune Defic Syndr 2007; 44:179-187.

11. Sackoff JE, Hanna DB, Pfeiffer MR, Toryan LV. Causes of Death among Persons with AIDS in the Era of Highly Active Antiretroviral Therapy: New York City. Ann Intern Med 2006; 145:397-406.

12. Crum NF, Riffenburgh RH, Wegner S et al. Comparisons of causes of death and mortality rates among HIV infected persons: analysis of the pre-, early, and late HAART (highly active antiretroviral therapy) eras. J Acquir Immune Defic Syndr. 2006; 41:194-200. [PMID: 16394852].

13. Pacheco AG, Tuboi SH, Faulhaber JC, Harrison LH, Schechter M. Increase in non-AIDS related conditions as causes of death among HIV-infected individuals in the HAART era in Brazil. PLoS ONE 2008; 3:e1531.

14. Jain MK, Skiest DJ, Cloud JW et al. Changes in mortality related to human immunodeficiency virus infection: comparative analysis of inpatient deaths in 1995 and in 1999-2000. Clin Infect Dis 2003; 36(8):1030-8.

15. Martınez E, Milinkovic A, Buira E et al. Incidence and causes of death in HIV-infected persons receiving highly active antiretroviral therapy compared with estimates for the general population of similar age and from the same geographical area. HIV Med 2007; 8(4),251-8.

16. Palella FJ Jr, Baker RK, Moorman AC et al. HIV Outpatient Study Investigators. Mortality in the highly active antiretroviral therapy era: changing causes of death and disease in the HIV outpatient study. J Acquir Immune Defic Syndr. 2006; 43:27-34.

17. Yang CH, Huang YF, Hsiao CF et al. Trends of mortality and causes of death among HIV-infected patients in Taiwan, 1984-2005. British HIV Association HIV Medicine 2008; 9:535-543.

18. Pacheco AG, Tuboi SH, May SB et al. Temporal Changes in Causes of Death Among HIV-Infected Patients in the HAART Era in Rio de Janeiro, Brazil. J Acquir Immune Defic Syndr 2009; 51(5):624-30.

19. Lewden C, Thierry M, Rosenthal E et al. Changes in Causes of Death Among Adults Infected by HIV Between 2000 and 2005: The "Mortalite 2000 and 2005" Surveys (ANRS EN19 and Mortavic). JAIDS 2008; 48(5):590-8. 
20. Justman JE, Benning L, Danoff A et al. Protease inhibitor use and the incidence of diabetes mellitus in a large cohort of HIV-infected women. J Acquir Immune Defic Syndr 2003; 32(3):298-302.

21. Dever LL, Onwari PA, Figueroa WE, O’Donovan CA, Eng RH. Hyperglycemia associated with protease inhibitors in an urban HIV-infected minority based population. Ann Pharmacother. 2000; 34:580-4.

22. Carr A, Samaras K, Thorisdottir A et al. Diagnosis, prediction, and natural course of HIV-1 protease-inhibitor-associated lipodystrophy, hyperlipidaemia, and DM: a cohort study. Lancet 1999; 353:2093-9.

23. Dube MP, Edmondson-Melancon H, Qian D et al. Prospective evaluation of the effect of initiating indinavir-based therapy on insulin sensitivity and B-cell function in HIV-infected patients. J Acquir Immune Defic Syndr. 2001; 27(2):130-4.

24. Stein MD, Hanna L, Natarajan R et al. Alcohol use patterns predict high-risk HIV behaviors among active injection drug users. Journal of Substance Abuse Treatment. 2000; 18(4):359-63.
25. Windle M. The trading of sex for money or drugs, sexually transmitted diseases (STDs), and HIV-related risk behaviors among multisubstance using alcoholic inpatients. Drug and Alcohol Dependence 1997; 49(1):33-8.

26. Avins AL, Woods WJ, Lindan CP et al. HIV infection and risk behaviors among heterosexuals in alcohol treatment programs. JAMA 1994; 271(7):515-8.

27. Boscarino JA, Avins AL, Woods WJ et al. Alcohol-related risk factors associated with HIV infection among patients entering alcoholism treatment: Implications for prevention. Journal of Studies on Alcohol. 1995; 6(6):642-53.

28. Malow RM, Dévieux JG, Jennings T, Lucenko BA, Kalichman SC. Substance-abusing adolescents at varying levels of HIV risk: Psychosocial characteristics, drug use, and sexual behavior. J Subst Abuse 2001;13:103-17.

29. Weber R, Sabin CA, Friis-Møller N et al. Liver-related deaths in persons infected with the human immunodeficiency virus: the D:A:D study. Arch Intern Med. 2006;166(15):1632-41. 